\title{
The Effect of Microporous Layer in Phosphoric Acid Doped Polybenzimidazole Polymer Electrolyte Membrane Fuel Cell
}

\author{
Muhammet Çelik', Gülşah Özışık², Gamze Genç²* and Hüseyin Yapıcı
}

${ }^{1}$ Aksaray Üniversitesi, Mühendislik Fakültesi, Makine Mühendisliği Bölümü 68100 Aksaray, Turkey

${ }^{2}$ Erciyes Üniversitesi, Mühendislik Fakültesi, Enerji Sistemleri Mühendisliği Bölümü 38039 Kayseri, Turkey

\begin{abstract}
A polybenzimidazole $(\mathrm{PBI})$ based polymer electrolyte fuel cells, which called high temperature polymer electrolyte fuel cells (HT-PEMS), operate at higher temperatures $\left(120-200^{\circ} \mathrm{C}\right)$ than conventional PEM fuel cells. Although it is known that HT-PEMS have some of the significant advantages as non-humidification requirements for membrane and the lack of liquid water at high temperature in the fuel cell, the generated water as a result of oxygen reduction reaction causes in the degradation of these systems. The generated water absorbed into membrane side interacts with the hydrophilic PBI matrix and it can cause swelling of membrane, so water transport mechanism in a Membrane Electrode Assembly (MEA) needs to be well understood and water balance must be calculated in MEA Therefore, the water diffusion transport across the electrolyte should be determined. In this study, it is investigated firstly the water content in a MEA in the case of with/without Microporous Layer (MPL). Secondly, in the case of with MPL the effect of microporous layer's thickness on the water management in fuel cell is investigated. For this aim, two-dimensional fuel cell with interdigitated flow-field is modeled using Comsol Multiphysics 4.2a software. The operating temperature and doping level is selected as $180^{\circ} \mathrm{C}$ and $6.75 \mathrm{RPU}_{3} \mathrm{PO}_{4} / \mathrm{PBI}$, respectively. The results of this work brought out that MPL significantly effects to water content in MEA and reduces $\mathrm{H}_{2} \mathrm{O}$ concentration in MEA. Thus it can be prevented to flooding in MEA and so durability of the cell is increased.
\end{abstract}

Keywords: Clean energy technologies; Hydrogen energy; $\mathrm{H}_{3} \mathrm{PO}_{4}$ doped PBI membrane PEM fuel cell

\section{Introduction}

There is a growing demand for highly efficient, zero pollution fuel cell power sources for a wide variety of applications including automotive, stationary, and portable systems. For stationary, emergency back-up, and telecommunications systems, high temperature polymer electrolyte fuel cells (HT-PEMS), which operate at significantly higher temperatures $\left(120-200^{\circ} \mathrm{C}\right)$ than conventional PEM fuel cells, are under rapid development. In particular, phosphoric acid doped Polybenzimidazole (PBI) based membranes show the most promise for HT-PEMs. Thermochemical stability and proton conductivity can be enhanced by doping with phosphoric acid. Although the lack of liquid water at high temperature and zero humidification requirements are often cited as a major advantage of PBI-based HT-PEMS, the water that is generated by reaction plays a major role in the degradation of these systems due to the fact that it limits obtaining of high current density. Therefore, it needs to be precisely understood. The most attractive way is using the Microporous Layer (MPL) at the both electrodes (anode and cathode) for more removal of excessive liquid water. MPL is next to the catalyst layer and more hydrophobic. The researchers made a lot of studies about the effect of MPL on fuel cell performance [1-15]. And the key findings of these studies can be given briefly as follows: (i) The ohmic losses can be reduced by using the MPL since higher hydraulic pressure as a result of acting capillary barrier to liquid water, (ii) Mass transport of protons and electrons can be enhanced by using MPL, (iii) With MPL, more uniform water distribution profiles can be obtained, (iv) The strength of fuel cell can be enhanced with MPL since it acts as a buffer layer between the catalyst layer and diffusion layer.

This study presents the distribution of the water concentration in a Membran Electrode Assembly (MEA) in the case of with/without microporous layer (MPL). Furthermore, the effect of microporous layer's thickness on the water management in fuel cell is investigated in the case of with MPL.

\section{Mathematical model}

Computational domain contains six layers which are anode/cathode gas diffusion layers, anode/cathode catalyst layers, membrane and microporous layer inside cathode. Interdigitated channels are chosen as flow channel to diffuse reactant gases and to transfer water which produces in oxygen reduction reaction, gorgeously. Since both anode and cathode catalyst layers are very thin, these layers are assumed as reactive boundaries in the fuel cell modeling. Schematic illustration of a phosphoric acid $\left(\mathrm{H}_{3} \mathrm{PO}_{4}\right)$ doped $\mathrm{PBI}$ membrane PEM fuel cell is shown in Figure 1.

The assumptions used in numerical model are as follows;

- Steady state condition

- Cell temperature is constant

- Single phase (Fuel, oxidant and produced water are in gas phase)

- All porous materials are isotropic and homogenous in all directions (GDL, CL, Membrane)

- Ideal gas mixtures

- Flow is laminar and incompressible in the flow channels

- Perfect contact in between all interfaces of components

*Corresponding author: Gamze Genç, Erciyes Üniversitesi, Mühendislik Fakültesi, Enerji Sistemleri Mühendisliği Bölümü 38039 Kayseri, Turkey, E-mail: gamzegenc@erciyes.edu.tr

Received September 26, 2013; Accepted December 26, 2013; Published January 05, 2014

Citation: Çelik M, Özışık G, Genç G, Yapıcı H (2014) The Effect of Microporous Layer in Phosphoric Acid Doped Polybenzimidazole Polymer Electrolyte Membrane Fuel Cell. J Appl Mech Eng 3: 133. doi:10.4172/2168-9873.1000133

Copyright: $\odot 2014$ Çelik M, et al. This is an open-access article distributed under the terms of the Creative Commons Attribution License, which permits unrestricted use, distribution, and reproduction in any medium, provided the original author and source are credited. 

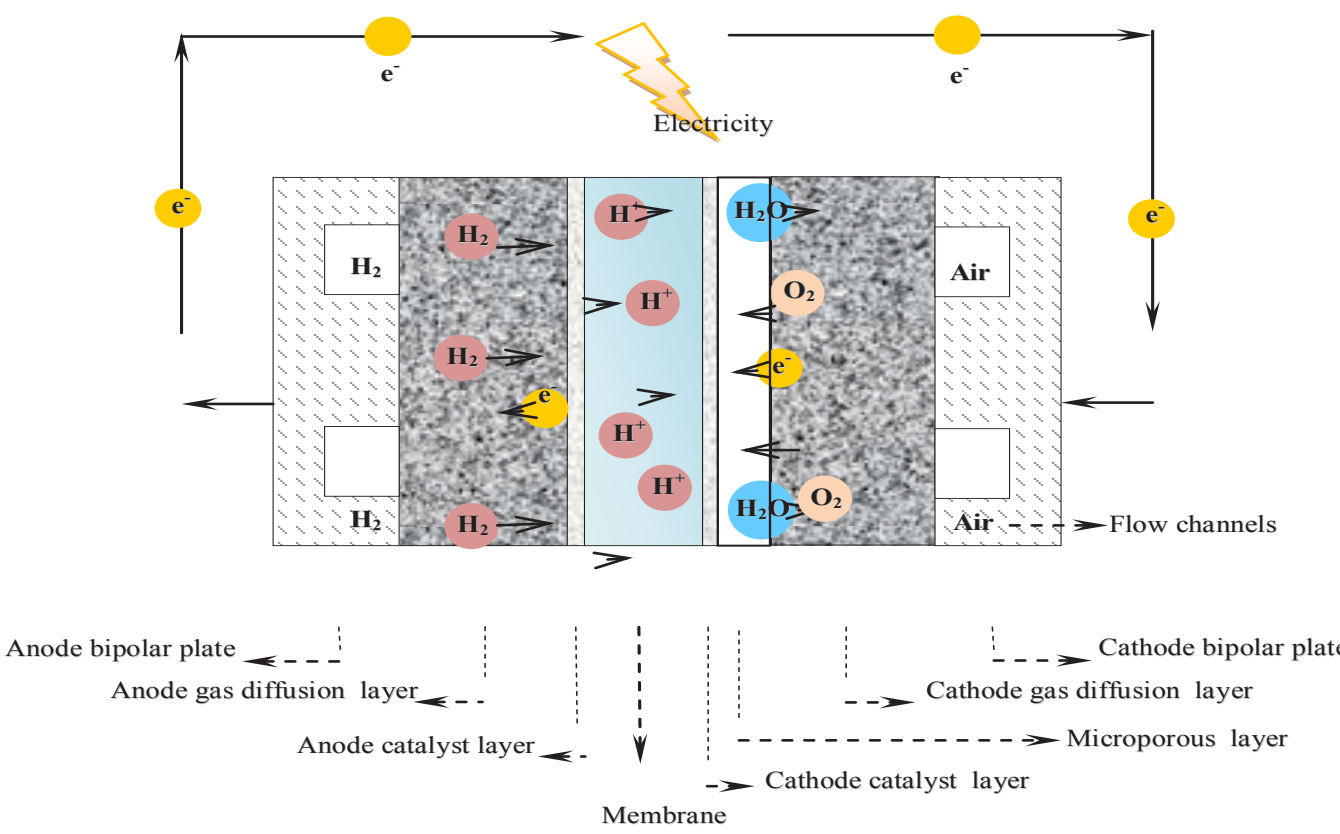

Figure 1: Schematic illustration of a PEM fuel cell [16].

\section{Governing equations}

Mechanistic models used in modeling for PEM fuel cell can be subcategorized as single and multi domain approaches. As governing equations are separately solved with appropriate boundary conditions for each domain in the multi domain approach, a single governing equation is solved for a computational domain by adding source terms determined for each component in the single domain approach. In this study, multi domain approach will be used for phosphoric acid doped PBI membrane PEM fuel cell modeling. Furthermore, in order to simplify modeling, catalyst layers will take into account as reactive boundaries. Model equations and boundary conditions are prescribed for each domain forming the fuel cell.

\section{Anode/Cathode Gas Diffusion Layers (GDL) and Microporous Layer (MPL)}

Governing equations are species conservation equation, charge conservation equation (e-) and momentum conservation equation. Due to being porous media of diffusion layers, velocity distribution is formulated with Darcy's law and conservation of mass (continuity) equations:

$$
\begin{aligned}
& u=-\frac{k_{p}}{\mu} \cdot \nabla P \\
& \nabla \cdot(\rho \cdot u)=0
\end{aligned}
$$

where, $u$ is fluid velocity, $k_{p}$ is permeability of GDL and MPL, $\mu$ is viscosity of fluid and $\nabla P$ is pressure difference an between flow channel inlet and outlet. Stefan Maxwell equation is used to transfer each gas species $\left(\mathrm{H}_{2}, \mathrm{H}_{2} \mathrm{O}, \mathrm{O}_{2}\right)$ :

$$
\rho \cdot u \cdot \nabla m_{i}=\nabla \cdot\left[\rho \cdot \varepsilon \cdot m_{i} \sum_{j=1}^{N} D_{i, j}^{\text {eff }}\left\{\frac{M}{M_{i}}\left(\nabla m_{i}+m_{i} \frac{\nabla M}{M}\right)\right\}\right]
$$

$m_{i}$ is mass fraction of reactants, $D^{\text {eff }}$ is effective diffusion coefficient of species and is defined as follows;

$$
D_{i}^{e f f}=D_{i j} \cdot \varepsilon^{1.5}
$$

where, $D_{i j}$ is binary diffusion coefficient at reference temperature and pressure. It is described as flows for each pairs of gases;

$$
\begin{aligned}
& D_{\mathrm{H}_{2} \mathrm{H}_{2} \mathrm{O}}=9.15 \cdot 10^{-5} \cdot\left(\frac{T}{307.1}\right)^{1.75} \\
& D_{\mathrm{N}_{2} \mathrm{H}_{2} \mathrm{O}}=2.56 \cdot 10^{-5} \cdot\left(\frac{T}{307.1}\right)^{1.75} \\
& D_{\mathrm{O}_{2-} \mathrm{N}_{2}}=2.2 \cdot 10^{-5} \cdot\left(\frac{T}{293.2}\right)^{1.75} \\
& D_{\mathrm{O}_{2} \mathrm{H}_{2} \mathrm{O}}=2.82 \cdot 10^{-5} \cdot\left(\frac{T}{308.1}\right)^{1.75}
\end{aligned}
$$

Charge conservation equation for e-:

$\nabla\left(-\sigma_{s} \cdot \nabla \phi_{s}\right)=0$

\section{Anode/Cathode catalyst layers}

Velocity distribution is determined using the continuity equations because the catalyst layers consist of porous structure such as a gas diffusion layers.

$$
\nabla(u \cdot \rho)=S_{i}
$$

Where $S_{i}$ is source terms which calculated from Faraday Law. They are explained as follows;

$$
S_{H_{2}}=-\frac{i}{2 \cdot F}
$$




$$
\begin{gathered}
S_{\mathrm{O}_{2}}=\frac{i}{4 \cdot F} \\
S_{\mathrm{H}_{2} \mathrm{O}}=\frac{i}{2 \cdot F}
\end{gathered}
$$

Gas species in the catalyst layer are insoluble. Dissolved species transfer is modeled with Fick's law.

$$
\nabla\left(u \cdot c_{i}\right)-\nabla\left(D_{i}^{e f f} \nabla c_{i}\right)=S_{i}
$$

Charge conservation equation for $\mathrm{H}+$ and $\mathrm{e}-$ is written, separately.

For e- (anode):

$$
-\sigma_{s} \cdot \nabla \phi_{s}=-i_{a}
$$

For $\mathrm{H}+($ anode);

$$
-\sigma_{e} \cdot \nabla \phi_{e}=i_{a}
$$

For e- (cathode);

$$
-\sigma_{s} \cdot \nabla \phi_{s}=-i_{c}
$$

For $\mathrm{H}+$ (cathode);

$$
-\sigma_{e} \cdot \nabla \phi_{e}=i_{c}
$$

Eqns (9) and (11) represent electron transport through solid phase. Where, $\sigma_{\mathrm{s}}$ is electrical conductivity of solid material and $\phi_{\mathrm{s}}$ is solid phase potential. Eqns (10) and (12) represent hydrogen proton transport through electrolyte phase. Catalyst layer has mixed conductivity (ionic conductivity and electrical conductivity). Therefore, both charge equation for electron and charge equation for proton are equal to total current in the anode or cathode electrode. Where, $\sigma_{\mathrm{e}}$ is ionic conductivity of electrolyte and $\phi_{\mathrm{e}}$ is electrolyte phase potential. Anode and cathode current densities are prescribed with Butler Volmer equation.

$$
i_{a, c}=i_{0} \cdot\left[\exp \left(\frac{\alpha_{a} \cdot F \cdot \eta}{R_{u} \cdot T}\right)-\exp \left(\frac{-\alpha_{c} \cdot F \cdot \eta}{R_{u} \cdot T}\right)\right]
$$

where, $i_{0}$ is reference exchange current density, $\alpha$ is charge transfer coefficient, $F$ is faraday constant, $R_{u}$ is ideal gas constant, $T$ is cell temperature and $\eta$ is over potential. Anode activation over potential $(\eta)$ can be expressed as follows;

$$
\eta=\phi_{s}-\phi_{e}
$$

Activation overpotential required to drive a electrochemical reaction rate across electrode (carbon and Pt particles)/electrolyte interface is potential difference in the double layer which occurs in triple phase boundary (between solid electrode and electrolyte).

Cathode activation over potential $(\eta)$ can be expressed as follows;

$$
\eta=\phi_{s}-\phi_{e}-V_{o c}
$$

Where, $V_{o c}$ is thermodynamic open circuit voltage of the cell and can be derived from Nernst equation.

$$
V_{o c}=-\frac{\Delta G}{n \cdot F}+\frac{R_{u} \cdot T}{n \cdot F} \cdot \ln \left(\frac{a_{H_{2}} \cdot a_{o_{2}}^{0.5}}{a_{\mathrm{H}_{2} \mathrm{O}}}\right)
$$

where, $\Delta G$ is Gibbs free energy, $n$ is charge number, $F$ is faraday constant, $R_{u}$ is ideal gas constant, $T$ is cell temperature, $a$ is activity of species related with mole fraction of species and cathode pressure.

\section{Membrane}

Governing equations for this domain are conservation equation of mass $\left(\mathrm{H}^{+}, \mathrm{H}_{2} \mathrm{O}\right)$ and conservation equation of charge $\left(\mathrm{H}^{+}\right)$.

For hydrogen proton transport;

$$
\begin{aligned}
& i_{\text {ion }}=-\sigma_{m} \cdot \nabla \phi \\
& \nabla i_{\text {ion }}=0
\end{aligned}
$$

The ionic conductivity of PBI membrane which depends on strongly acid doping level $(\mathrm{X})$ and cell temperature $(\mathrm{T})$ is expressed as follows:

$$
\sigma_{m}=\frac{100}{\mathrm{~T}} \cdot \exp \left[8.0219-\left(\frac{2605.6-70.1 \cdot \mathrm{X}}{\mathrm{T}}\right)\right]
$$

The water vapor transfer in membrane;

$$
\begin{aligned}
& \nabla J_{\mathrm{H}_{2} \mathrm{O}}=0 \\
& J_{\mathrm{H}_{2} \mathrm{O}}=-D_{\mathrm{H}_{2} \mathrm{O}} \cdot \nabla c_{\mathrm{H}_{2} \mathrm{O}}
\end{aligned}
$$

The following expressions that are viscosities and velocities of reactants depending on cell temperature are integrated in numerical model. The values of viscosity for anode and cathode;

$$
\mu_{a}=8.76 \cdot 10^{-6} \cdot\left(\frac{(293.85+72)}{T+72}\right) \cdot\left(\frac{T}{293.85}\right)^{1.5}
$$

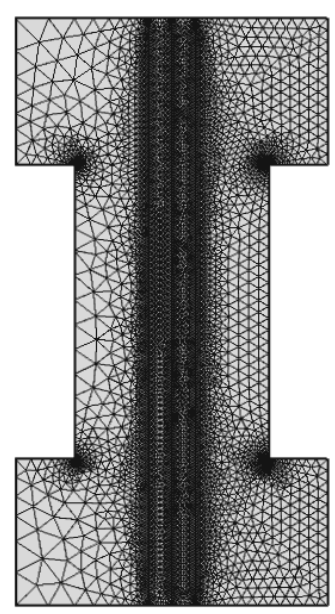

Figure 2: Grid structure of the PEM fuel cell model.

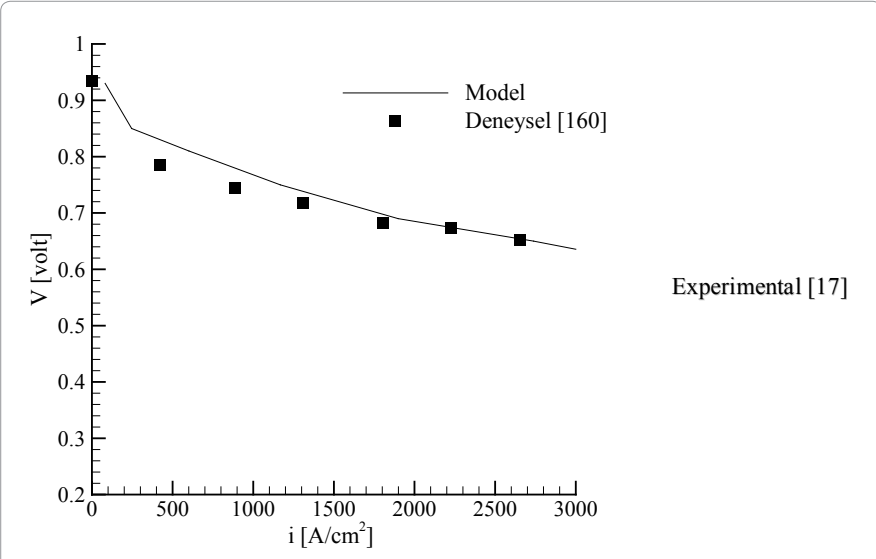

Figure 3: Comparison of numerical and experimental results [16]. 
(a)

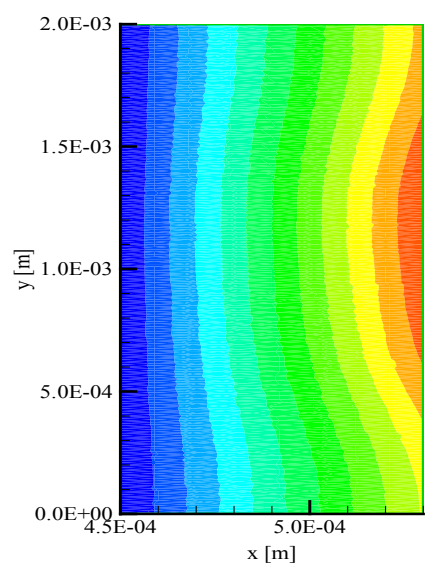

(b)

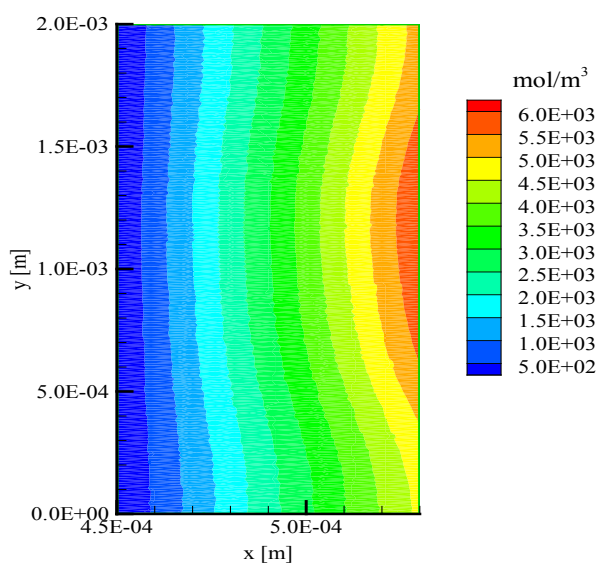

(c)
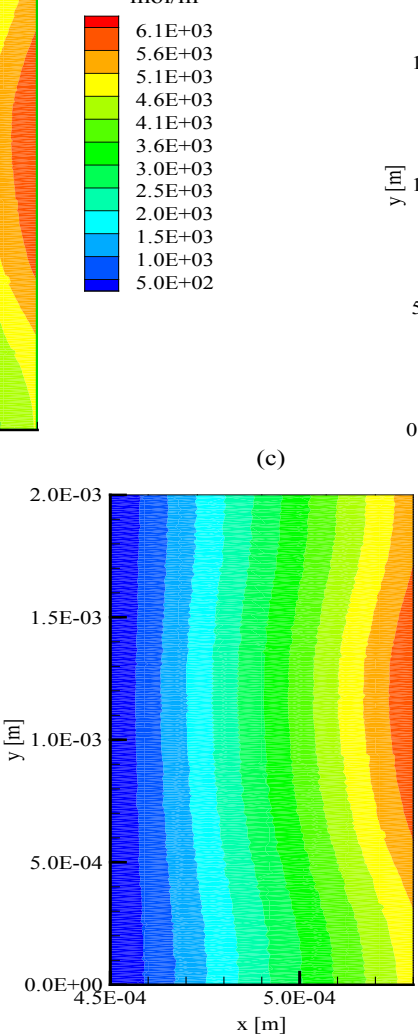

$\mathrm{mol} / \mathrm{m}^{3}$

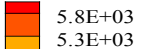

$5.3 \mathrm{E}+03$

$4.8 \mathrm{E}+03$

$4.4 \mathrm{E}+03$

$3.9 \mathrm{E}+03$

$.4 \mathrm{E}+03$

$2.9 \mathrm{E}+03$

. $4 \mathrm{E}+03$

$1.9 \mathrm{E}+03$

$1.5 \mathrm{E}+03$

$9.8 \mathrm{E}+02$

$5.0 \mathrm{E}+02$

Figure 4: The distribution of $\mathrm{H}_{2} \mathrm{O}$ concentration in MEA for different thickness of MPL. [(a) $2 \times 10^{-5} \mathrm{~m}$, (b) $8 \times 10^{-5} \mathrm{~m}$ and (c) $\left.16 \times 10^{-5} \mathrm{~m}\right]$.

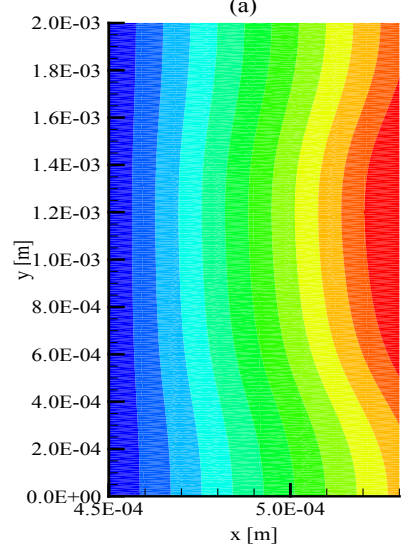

(a)

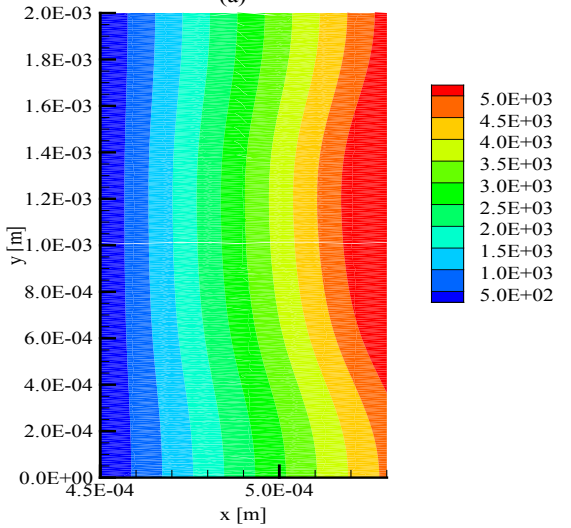

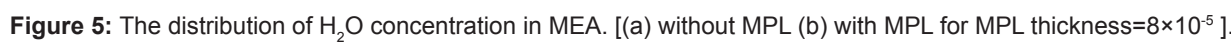

$$
\mu_{c}=2.018 \cdot 10^{-5} \cdot\left(\frac{(292.25+127)}{T+127}\right) \cdot\left(\frac{T}{292.25}\right)^{1.5}
$$

The values of velocity for anode and cathode;

$$
U_{\text {in_anot }}=\lambda_{a} \cdot \frac{i_{a} \cdot A_{M E A} \cdot X_{H_{2}} \cdot R \cdot T}{2 \cdot F \cdot P_{a} \cdot A_{g c}}
$$

$$
U_{\text {in_katot }}=\lambda_{c} \cdot \frac{i_{c} \cdot A_{M E A} \cdot X_{O_{2}} \cdot R \cdot T}{4 \cdot F \cdot P_{c} \cdot A_{g c}}
$$

where, $A_{M F A}$ is active surface area, $X_{i}$ is mole fraction of reactants, $\lambda$ is stoichiometric ratio, $P_{i}$ is pressure of reactant, $A_{g c}$ is surface area of gas channel. 
Citation: Çelik M, Özışık G, Genç G, Yapıcı H (2014) The Effect of Microporous Layer in Phosphoric Acid Doped Polybenzimidazole Polymer Electrolyte Membrane Fuel Cell. J Appl Mech Eng 3: 133. doi:10.4172/2168-9873.1000133
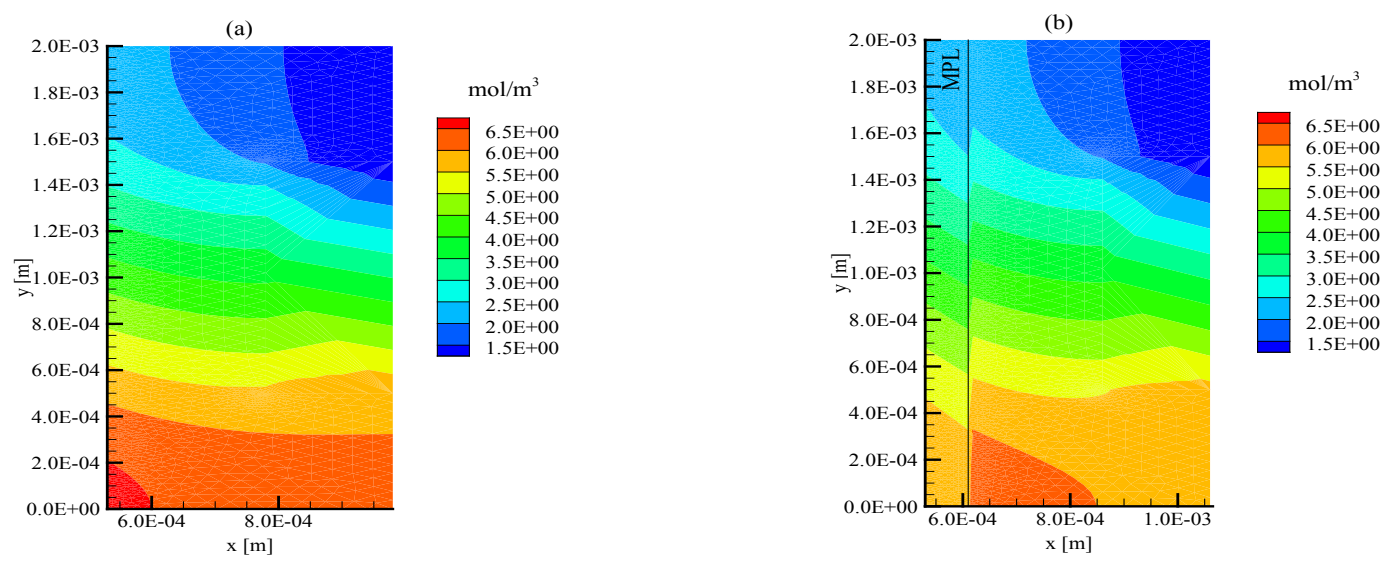

Figure 6: The distribution of $\mathrm{H}_{2} \mathrm{O}$ concentration in cathode side of fuel cell. [(a) without MPL (b) with MPL for MPL thickness=8 $\times 10^{-5}$.

\begin{tabular}{|c|c|c|}
\hline Parameters & Unit & Value \\
\hline Channel height, $\mathrm{H}_{\text {channel }}$ & $\mathrm{m}$ & 7.50E-04 \\
\hline Channel width, $\mathrm{W}_{\text {channel }}$ & $\mathrm{m}$ & 0.002 \\
\hline Rib width, $W_{\text {rib }}$ & $\mathrm{m}$ & 5.00E-04 \\
\hline GDL thickness, $\mathrm{H}_{\mathrm{GDL}}$ & $\mathrm{m}$ & $2.50 \mathrm{E}-04$ \\
\hline$C L$ thickness, $\mathrm{H}_{\text {elektrot }}$ & $\mathrm{m}$ & 1.00E-05 \\
\hline Membrane thickness, $\mathrm{H}_{\text {membran }}$ & $\mathrm{m}$ & 8.00E-05 \\
\hline MPL thickness & $\mathrm{m}$ & 8.00E-05 \\
\hline GDL porosity, $\varepsilon_{\mathrm{GDL}}$ & - & 0.4 \\
\hline GDL permeability, $\mathrm{K}_{\mathrm{GDL}}, \mathrm{M}_{\mathrm{PL}}$ & $\mathrm{m}^{2}$ & 1.80E-11 \\
\hline GDL electronic conductivity, $\sigma_{\mathrm{GDL}}$ & $\mathrm{S} / \mathrm{m}$ & 222 \\
\hline $\mathrm{H}_{2}$ inlet mass fraction (anode), $\mathrm{wH}_{2 \mathrm{~g}}$ & - & 0.743 \\
\hline $\mathrm{H}_{2} \mathrm{O}$ inlet mass fraction (cathode), $\mathrm{wH}_{2} \mathrm{O}_{\mathrm{g}}$ & - & 0.023 \\
\hline $\mathrm{O} 2$ inlet mass fraction (cathode), wO2g & - & 0.228 \\
\hline Hydrogen molar mass, $\mathrm{MH}_{2}$ & $\mathrm{~kg} / \mathrm{mol}$ & 0.002 \\
\hline Nitrogen molar mass, $\mathrm{MN}_{2}$ & $\mathrm{~kg} / \mathrm{mol}$ & 0.028 \\
\hline Molar mass of water, $\mathrm{MH}_{2} \mathrm{O}$ & $\mathrm{kg} / \mathrm{mol}$ & 0.018 \\
\hline Oxygen molar mass, $\mathrm{MO}_{2}$ & $\mathrm{~kg} / \mathrm{mol}$ & 0.032 \\
\hline $\mathrm{H}_{2}-\mathrm{H}_{2} \mathrm{O}$ binary diffusion coefficient, $\mathrm{D}_{\mathrm{H}^{\prime}{ }^{\prime} \mathrm{H} 2 \mathrm{O}}$ & $\mathrm{m}^{2} / \mathrm{s}$ & 9.15E-05 \\
\hline $\mathrm{N}_{2}-\mathrm{H}_{2} \mathrm{O}$ binary diffusion coefficient, $\mathrm{D}_{\mathrm{N} 2, \mathrm{H} 2 \mathrm{O}}$ & $\mathrm{m}^{2} / \mathrm{s}$ & $2.56 \mathrm{E}-5$ \\
\hline $\mathrm{O}_{2}-\mathrm{N}_{2}$ binary diffusion coefficient, $\mathrm{D}_{\mathrm{O} 2, \mathrm{~N} 2}$ & $\mathrm{~m}^{2} / \mathrm{s}$ & 2.20E-05 \\
\hline $\mathrm{O}_{2}-\mathrm{H}_{2} \mathrm{O}$ binary diffusion coefficient, $\mathrm{D}_{\mathrm{O} 2, \mathrm{H} 2 \mathrm{O}}$ & $\mathrm{m}^{2} / \mathrm{s}$ & 2.82E-05 \\
\hline Cell temperature, $\mathrm{T}$ & $\mathrm{K}$ & $180+273.15$ \\
\hline Reference pressure, $P_{\text {ref }}$ & $\mathrm{Pa}$ & 101320 \\
\hline Cell voltage, $\mathrm{V}_{\text {cell }}$ & Volt & 0.9 \\
\hline Oxygen reference concentration, $\mathrm{C}_{\mathrm{O} \text {,ref }}$ & $\mathrm{mol} / \mathrm{m}^{3}$ & 40.88 \\
\hline Hydrogen reference concentration, $\mathrm{C}_{\mathrm{H} 2 \text {,ref }}$ & $\mathrm{mol} / \mathrm{m}^{3}$ & 40.88 \\
\hline Membrane porosity, $\varepsilon_{\mathrm{m}}$ & - & 0.3 \\
\hline CL porosity, $\varepsilon_{\mathrm{cl}}$ & - & $1-\varepsilon_{m}-\varepsilon_{G D T}$ \\
\hline CL permeability, $\kappa_{c l}$ & $\mathrm{~m}^{2}$ & $\mathrm{~K}_{\mathrm{GDT}} / 5$ \\
\hline Acid doping level, $X$ & - & 6.75 \\
\hline Charge transfer coefficient (for anode) $\left[\alpha_{a, a}, \alpha_{a, c}\right]$ & & $0.5,0.5$ \\
\hline Charge transfer coefficient (for cathode) $\left[\alpha_{c, a}, \alpha_{c, c}\right]$ & & 1,1 \\
\hline Exchange current density (for anode) & $\mathrm{A} / \mathrm{m}^{2}$ & $1.00 \mathrm{E}+09$ \\
\hline Exchange current density (for cathode) & $\mathrm{A} / \mathrm{m}^{2}$ & 4.00E-02 \\
\hline
\end{tabular}

Table 1: Operating parameters.

\section{Boundary conditions}

The boundary conditions applied on the external surfaces of the computational domain are described as follows; anode gas flow channel inlet; $P=P_{a}, w=w_{H 2}, w=w_{H 2 O}$ anode gas flow channel outlet; $P=P_{\text {ref }}$ all

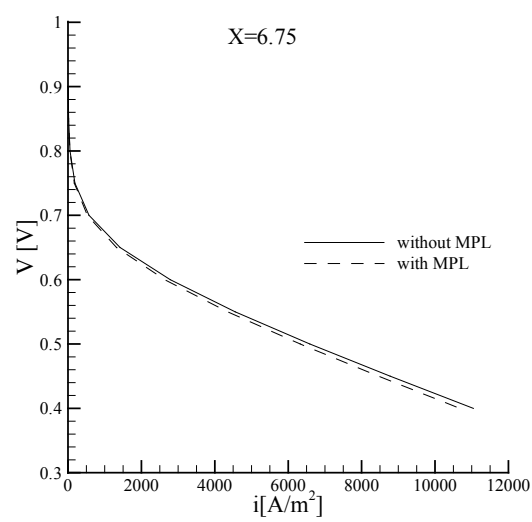

Figure 7: Polarization curves in the cases of with/without MPL.

external boundaries for anode side; $\frac{\partial c_{H_{2}, H_{2} \mathrm{O}}}{\partial n}=0, \frac{\partial P}{\partial n}=0$, cathode gas flow channel inlet; $P=P_{e}, w=w_{O 2^{2}}, w=w_{H 2 O^{\circ}}$ cathode gas flow channel outlet; $P=P_{\text {rep }}$ all external boundaries for cathode side; $\frac{\partial c_{\mathrm{O}_{2}, \mathrm{H}_{2} \mathrm{O}}}{\partial n}=0$, $\frac{\partial P}{\partial n}=0$, the external boundaries of anode and cathode bipolar plate; $\frac{\partial \phi_{e}}{\partial n}=0, \frac{\partial \phi_{s}}{\partial n}=0$, anode bipolar plate; $\phi_{s}=0$, cathode bipolar plate; $\phi_{s}=V_{o c}$. The each interface between all components is applied on interfacial boundary condition and both channels are assumed sufficiently long that velocity and species concentration fields are fully developed.

\section{Numerical Procedure}

COMSOL Multiphysics $4.2 a$ software based solution of the finite element approach is used in the numerical solutions. Operating parameters integrated the numerical model are illustrated in Table 1. A geometry and grid structure of the PEM fuel cell model is shown in Figure 2. Grid structure consists of 13111 triangular elements and it used PARDISO as solver. 


\section{Results and Discussion}

Figure 3 shows in comparison of the computed polarization curve with experimental one. The experimental data is adapted to the numerical model. As seen from this figure, the numerical model is accurately predicted to experimental results. Thus, it has been proven the accuracy of the model.

Figure 4 illustrates the distributions of $\mathrm{H} 2 \mathrm{O}$ concentrations in MEA which occurs from anode catalyst layer, membrane and cathode catalyst layer for different thicknesses of MPL. Microporous layer plays an important role in water transfer inside fuel cell. As microporous layer thickness increases form $2 \times 10^{-5}$ to $16 \times 10^{-5} \mathrm{~m}$, water content in MEA decreases. Ionic transport in PBI membrane depends on strongly phosphoric acid level and cell temperature. Since high water content in MEA causes phosphoric acid leakage from here, ionic conductivity of membrane decreases with the cell operating time. Therefore, the water content should be kept at a certain level.

The distributions of $\mathrm{H}_{2} \mathrm{O}$ concentrations in MEA is demonstrated in Figure 5 to present the effect of microporous layer in $\mathrm{H}_{3} \mathrm{PO}_{4}$ doped $\mathrm{PBI}$ membrane PEM fuel cell. As is shown in this figure, MPL significantly effects to water content in MEA and reduces $\mathrm{H}_{2} \mathrm{O}$ concentration in MEA. Thus it can be prevented to flooding in MEA and so durability of the cell is increased.

Figure 6 indicates to the distribution of $\mathrm{H}_{2} \mathrm{O}$ concentration in cathode side of fuel cell. In the case of with MPL, the distribution of water concentration declines in gas diffusion layer, especially under the rib.

In order to explain how the micro porous layer affects the cell performance, the polarization curves in the cases of with/without MPL are depicted in Figure 7. In the case of MPL, the cell performance does not change significantly under a single phase condition.

\section{Conclusion}

The distribution of $\mathrm{H}_{2} \mathrm{O}$ concentration in MEA and the cell performance are investigated for the cases of with/without MPL. The main conclusions can be given briefly as follows:

- In the case of with MPL, water content in MEA decreases with the increase of microporous layer thickness.

- In the gas diffusion layer, the distribution of water concentration declines by using a MPL.

- If water content in MEA is low, phosphoric acid leakage can be prevented and so the ionic conductivity of phosphoric acid doped PBI membrane can be made stable.

- There is no remarkable effect of MPL on the cell performance.

\section{Acknowledgements}

The authors would like to thank the Scientific and Technological Research Council of Turkey (TÜBITAK) for funding supported by project coded $111 \mathrm{M} 071$.

\section{References}

1. Nam JH, Kaviany M (2003) Effective diffusivity and water-saturation distribution in single- and two-layer PEMFC diffusion medium. International Journal of Heat and Mass Transfer 46: 4595-4611.
2. Pasaogullari U, Wang CY (2004) Two-phase transport and the role of microporous layer in polymer electrolyte fuel cells. Electrochimica Acta 49: 43594369.

3. Pasaogullari U, Wang CY, Chen KS (2004) Liquid Water Transport in Polymer Electrolyte Fuel Cells with Multi-Layer Diffusion Media. Proceedings of IMECE04 2004 ASME International Mechanical Engineering Congress and Exposition, Anaheim, California, USA

4. Weber AX, Newman J (2005) Effects of microporous layers in polymer electrolyte fuel cells. J Electrochem Soc 152: A677-A688.

5. Tseng CJ, Lou SK, Yan YY, Sung LY (2005) Gas Diffusion Layer and Microporous Layer for PEMFC, Proceedings International Hydrogen Energy Congress and Exhibition IHEC 2005, Istanbul, Turkey.

6. Atiyeh HK, Karan K, Peppley B, Phoenix A, Halliop E, et al. (2007) Experimenta investigation of the role of a microporous layer on the water transport and performance of a PEM fuel cell. Journal of Power Sources 170: 111-121.

7. Meng $H$ (2009) Multi-dimensional liquid water transport in the cathode of a PEM fuel cell with consideration of the micro-porous layer (MPL). International Journal of Hydrogen Energy 34: 5488-5497.

8. Kim T, Lee S, Park H (2010) A study of water transport as a function of the micro-porous layer arrangement in PEMFCs. International Journal of Hydrogen Energy 35: 8631-8643.

9. Swamy T, Kumbur EC, Mench MM (2010) Characterization of Interfacia Structure in PEFCs: Water Storage and Contact Resistance Model. Journal of The Electrochemical Society 157: B77-B85.

10. Chun JH, Park KT, Jo DH, Lee JY, Kim SG, et al. (2010) Determination of the pore size distribution of micro porous layer in PEMFC using pore forming agents under various drying conditions, International Journal of Hydrogen Energy 35: 11148-11153.

11. Tseng CJ, Lou SK (2010) Effects of microstructure characteristics of gas diffusion layer and microporous layer on the performance of PEMFC. Energy Conversion and Management 51: 677-684.

12. Wang X, Nguyen TV (2010) Modeling the Effects of the Microporous Layer on the Net Water Transport Rate Across the Membrane in a PEM Fuel Cell. Journal of The Electrochemical Society 157: B496-B505.

13. Nishiyama E, Murahashi $T$ (2011) Water transport characteristics in the gas diffusion media of proton exchange membrane fuel cell - Role of the microporous layer. Journal of Power Sources 196: 1847-1854.

14. Sasabe1 T, Tsushima S, Hirai S (2013) Effect of liquid water distribution in gas diffusion media with and without microporous layer on PEM fuel cell performance, Electrochemistry Communications 34: 239-241.

15. Özışık G (2013) Nükleer Hidrojen Üretimi ve Üretilen Hidrojenin Polimer Elektrolit Membranlı Yakıt Hücrelerinde Uygulaması, PhD Thesis, Erciyes Üniversitesi.

16. Wang JT, Savinell RF, Wamright J, Lrrr M, Yu H (1996) A H2/O2 Fuel cell using acid doped polybenzimidazole as polymer electrolyte. Elecrtrochimica Acta 41: 193-197. 